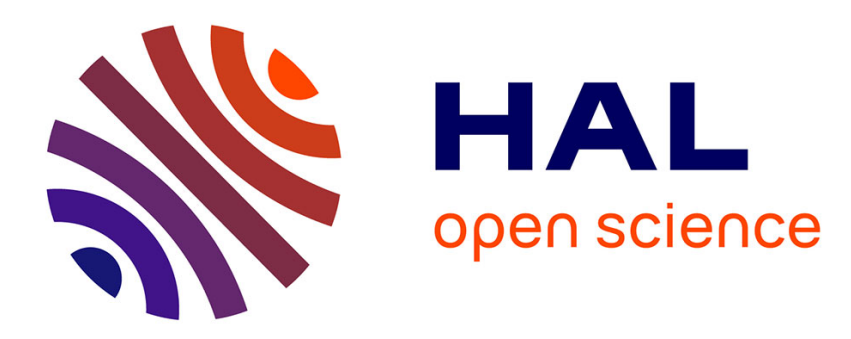

\title{
Brands as labour rights advocates? Potential and limits of brand advocacy in global supply chains \\ Chikako Oka
}

\section{To cite this version:}

Chikako Oka. Brands as labour rights advocates? Potential and limits of brand advocacy in global supply chains. Business Ethics: A European Review, 2018, 27 (2), pp.95-107. 10.1111/beer.12172 . hal-02952138

\section{HAL Id: hal-02952138 \\ https://hal.science/hal-02952138}

Submitted on 29 Sep 2020

HAL is a multi-disciplinary open access archive for the deposit and dissemination of scientific research documents, whether they are published or not. The documents may come from teaching and research institutions in France or abroad, or from public or private research centers.
L'archive ouverte pluridisciplinaire HAL, est destinée au dépôt et à la diffusion de documents scientifiques de niveau recherche, publiés ou non, émanant des établissements d'enseignement et de recherche français ou étrangers, des laboratoires publics ou privés. 


\title{
Brands as labour rights advocates? \\ Potential and limits of brand advocacy in global supply chains
}

\author{
Chikako Oka \\ chika.oka@royalholloway.ac.uk \\ School of Management \\ Royal Holloway University of London
}

How to cite this article: Oka C. (2017). Brands as labour rights advocates? Potential and limits of brand advocacy in global supply chains. Business Ethics: A European Review. 2017;00:1-13. https://doi.org/10.1111/beer.12172

\begin{abstract}
There is a growing phenomenon of brand advocacy, where brands pressure a producer country government to take pro-worker actions such as respecting the rights of activists and raising minimum wages. This article examines the potential and limits of brand advocacy by developing a conceptual framework and analysing three recent cases of brand advocacy in Cambodia's garment industry. The study shows that brands' action and influence are shaped by issue salience, mobilization structures, political opportunities/contexts, and resource dependency. This article makes both empirical and theoretical contributions. This is one of the first studies delving into the advocacy role of brands in promoting labour rights and conditions vis-a-vis government. Moreover, the article develops a testable framework specifying the conditions under which brands are likely to respond, act collectively, and influence government for pro-worker change. It also offers novel insights by applying social movement lenses and casting brands as social movement actors.
\end{abstract}




\section{Introduction}

On the $3^{\text {rd }}$ of January 2014 , minimum-wage strikes were violently crushed by the military police, killing five garment workers and wounding more than thirty in Cambodia's capital. 23 union leaders and workers were detained for months without trial. This deadly incident widely covered by the international media provoked public outcries and calls to release the detained activists. A large group of brands and global union federations formed a united front and wrote joint letters and engaged in talks with the Cambodian government. After months of pressuring and brands' credible threat of withdrawing orders, the detained activists were finally released.

This episode illustrates how brands, often targeted by activists and the media as the culprit of sweatshop conditions, are increasingly acting as labour rights advocates vis-à-vis producer country governments. This phenomenon, which I call brand advocacy, is particularly interesting given that corporate social responsibility (CSR) efforts to improve labour rights and conditions in global supply chains have known serious limitations. Scholars find that the progress made thanks to the CSR approach through codes of conduct and monitoring has been largely limited to safety and health issues (Barrientos \& Smith 2007, Bartley \& EgelsZandén 2015), while it has failed to address workers' right to organization and living wages (Anner 2012, Locke 2013, Egels-Zandén \& Merk 2014). Moreover, the CSR approach to labour tends to address visible issues notably child labour while leaving fundamental conditions unchanged (Jamali et al. 2017).

Scholars increasingly recognize that improving labor conditions in global supply chains requires a confluence of forces. Locke (2013) argues that private regulation has the best chance of succeeding when layered on and interacted with public regulation. Donaghey et al. (2014) argue that "symbiotic governance", combining consumer power and labour power is 
likely to drive progress in labour conditions in global supply chains. Similarly, Gereffi \& Lee (2016) maintain that "synergistic governance", or alliances of public, private, and social governance actors, offers a promising pathway for social and economic upgrading in global supply chains. Nonetheless, the conditions under which such layered, symbiotic, or synergistic governance emerges and the processes of how that works on the ground remain understudied. Scholars have examined complementarity between public and private labour regulation (Amengual 2010, Coslovsky \& Locke 2013, Locke et al. 2013), interactions between state regulators and civil society actors (Distelhorst et al. 2015), as well as transnational solidarity networks (Rodriguez-Garavito 2005, Anner 2013). Although important, these efforts largely focus on the factory-level, limiting their reach and impact.

Based on three cases of brands' political intervention in Cambodia's garment industry, this article shows that brand advocacy (i.e. pressuring a producer country government for proworker action) is a new form of boomerang politics with potential to make sector-wide changes despite limitations. This study develops a conceptual framework and illustrates with case evidence that brand advocacy can prompt state to take pro-worker actions under certain circumstances: when brands perceive issue salience, when mobilization structures are in place, when political opportunities/contexts are favourable, and when there is resource dependence.

This study makes important contributions to the literature both empirically and theoretically. Empirically, this is one of the first in-depth studies examining the advocacy role of brands in promoting labour rights and conditions vis-à-vis a producer country government. Theoretically, this article contributes a typology of boomerang politics in global supply chains and develops a conceptual framework specifying the conditions under which brands are likely to respond, act collectively, and influence a producer country government for pro-worker change. The novelty here is to cast brands as social movement actors rather than simple 
targets and to show the relevance of social movement theory to the study of corporate activism.

This article proceeds as follows. The next section discusses three types of boomerang politics and argues that brand advocacy represents a new boomerang pattern. The subsequent section develops a conceptual framework drawing on the theories of issue salience, social movements, and resource dependence. This is followed by a section outlining the context and method and a section examining three cases (crackdown, minimum wage increase, and trade union law). The article then summarizes the case evidence and concludes with broader implications.

\section{Varieties of boomerang politics}

One well-known form of governance involving public, private, and social actors is a "boomerang" pattern of influence. The original boomerang model developed by Keck \& Sikkink (1998) posits that when domestic channels for expressing dissent and resolving demands are blocked, transnational alliances of civil society actors appeal foreign governments to intervene in the face of a recalcitrant domestic government. Keck \& Sikkink's state-centric boomerang model has been applied to corporate settings, where corporations have become the ultimate target of campaigns to save the rainforest (McAteer \& Pulver 2009) and to address labour standard violations in global supply chains (Armbruster-Sandoval 2005, Rodriguez-Garavito 2005, Anner 2013) among others. Given the variants, den Hond \& de Bakker (2012) call the general pattern in which activist groups exert pressure on primary targets to influence the ultimate target as "boomerang politics".

The original boomerang model, where the ultimate pressure emanates from one state and gets applied to another state, can be termed state-to-state boomerang and is depicted in Figure 
1. This pattern has also been present in the area of international labour standards. Trade agreements have provided channels for civil society actors to pressure buyer country governments to exert influence on producer governments. Notable examples are the US General System of Preferences (GSP), which provides preferential market access to a number of products from developing countries on a condition that the countries respect internationally recognized worker rights. Civil society actors have used GSP petitions exposing labour rights violations to put pressure on the US government trade representatives, which in turn exert pressure on trading partners (Anner 2013). Nonetheless, this trade instrument is not available in all countries and its effectiveness depends on the level of influence the US government can exert (Caraway 2010).

---Insert Figure 1 about here---

In the past two decades, the target of activist pressure has shifted from state to firms, notably well-known brands and retailers of consumer goods, as global brands' power and resources have come to overshadow those of the state (Seidman 2007, Soule 2009, Anner 2013). While a general boomerang pattern targeting corporations has been called "corporate boomerang" (McAteer \& Pulver 2009), such pattern in the area of labour in global supply chains has been specifically referred to as "brand boomerang", given the pressure applied to brands (Bartley \& Egels-Zandén 2016). Brand boomerang campaigns target brands and "use networks with external allies to create publicity and multiple points of pressure to spur remediation" (Ibid.: 243). Most often, this takes the form of local unions or NGOs cooperating with global union federations (GUFs) and/or international NGOs to mobilize pressures on brands to address labour standard violations in their supplier facilities. This pattern can be called brand-to-supplier boomerang and is shown in Figure 2.

---Insert Figure 2 about here --- 
Such brand-to-supplier boomerang pattern was made famous in the 2000s with high-profile cases in Latin America (e.g. Armbruster-Sandoval 2005, Rodriguez-Garavito 2005). More recently, this brand boomerang pattern has won important victories : transnational alliances of workers, unions, and activists have pressured US universities to cut licensing contracts and obliged athletic apparel giants like Adidas, Nike and Russell Corporation to cover the termination costs of their suppliers (Anner 2013). While brand boomerang campaigns are well-known in Latin America, this pattern is also present in Asia, notably in Indonesia (Bartley \& Egels-Zandén 2016) and in Cambodia (Oka 2010).

Despite some notable successes, brand boomerang campaigns for labour have their limits. Seemingly successful campaigns may end up in failure as unions may be forced to dissolve or factories close and move elsewhere. It is telling that two of the brand boomerang campaigns that achieved transformative gains in Indonesia both ended up in factory closures (Bartley \& Egels-Zandén 2016). Inherently unstable and footloose nature of the garment and footwear industry made leveraging risky and gains rather limited (Ibid.). Even a successful brand-tosupplier boomerang case is limited by its very nature of being ad-hoc and supply-chain specific, as the pressure is exercised by brands and placed on their suppliers, creating pockets of best practice in the vast sea of labour standard violations.

There is another pattern of boomerang that leverages corporations but ultimately targets a state. Notable examples include the anti-Apartheid campaign (Seidman 2007) and the divestment campaign in Myanmar (den Hond \& de Bakker 2012), where corporations doing business with a racist or an autocratic regime came under pressure and they in turn put pressure on those states. This type of boomerang targeting brands but ultimately pressuring a government is on the rise, particularly in the global garment industry. In this new breed, which can be called brand-to-state boomerang and is depicted in Figure 3, brands are simultaneously targets and advocates. One important difference from the divestment 
campaign in Myanmar is that in brand-to-state boomerang, brands are actively engaging with the government and seeking to influence them rather than simply leaving the country.

$$
\text { ---Insert Figure } 3 \text { about here --- }
$$

Such brand-to-state boomerang has received little scholarly attention. One of the rare exceptions, den Hond et al. (2014) study Clean Clothes Campaigns (CCC)'s urgent appeal mechanisms, where $\mathrm{CCC}$ receives requests from workers around the world to intervene and solve labour standard violations. They find that only 16 percent of the urgent appeals received are state-focused (e.g. labour laws, imprisonment, murder or harassment of labour activists) as opposed to factory-focused demands and conclude that state-focused appeals are less likely to be resolved given the systemic cause of the underlying conflict. Precisely because of the systemic nature of the issue it can handle, however, the brand-to-state boomerang pattern has potential to tackle fundamental problems that the supply-chain specific CSR approach has failed to address.

\section{Conceptual framework}

Scholars studying boomerang politics have sought to identify the circumstances under which cross-border alliances of civil society actors achieve their goals. Keck \& Sikkink (1998) found issue resonance, network density (of activists), and target vulnerability as important conditions for transnational advocacy networks to achieve leverage and influence outcomes. The cohesiveness and strengths of activist networks and vulnerability of targets are also found to be important for the success of corporate boomerang (McAteer \& Pulver 2009) and for brand (-to-supplier) boomerang (Bartley \& Egels-Zandén 2016). Nonetheless, few studies have examined the conditions under which corporations or brands act as advocates promoting change vis-a-vis government. Drawing on the theories of issue salience, social movements, 
and resource dependence, this section develops a framework to help us understand when brands are likely to act collectively and exert influence over a state.

Issue salience

There is a growing scholarly consensus that a firm's responsiveness to stakeholders is driven by issue salience (Bundy et al. 2013, Dutton \& Jackson 1987, Eesley \& Lenox 2006). Bundy et al. (2013: 353) define issue salience as "the degree to which a stakeholder issue resonates with and is prioritized by management". The extant literature suggests that issue salience has both social and strategic dimensions, as firms are likely to act upon an issue when social expectations and normative pressures are important and when the issue is likely to significantly impact the business (e.g. Heath 1997, Lawrence \& Weber 2014). Bundy et al. (2013) maintain that when a stakeholder's issue resonates or conflicts with a firm's organizational identity and/or strategic frame, the firm is likely to respond to the stakeholder's issue in a substantive manner. Here, “...identity is related to organizational rhetoric and to the display of desired images, whereas strategic frames are related to calculative action aimed at achieving performance outcomes" (Bundy et al. 2013: 357). Thus, we can deem issue salience as consisting of image and performance dimensions, albeit their close link.

In the area of labour practices in global supply chains, naming and shaming has been the dominant mechanism through which activists have raised the level of issue salience by putting brand images at risk (Klein 1999). Through associating brand names to undesirable images, media-savvy activists have often obtained concessions from brands (Anner 2013). Moreover, strategic factors directly affecting firm performance also heighten issue salience. For instance, disruption to supply chains caused by strikes or unrest delays delivery and hurts sales, directly impacting firm performance. In short, brands are likely to respond when they see the issue has important implications for their images and/or firm performance. 
Mobilization structures and political opportunities

The literature on social movements seeks to understand, inter alia, factors and conditions that enable social movement actors to challenge and influence mainstream institutions, traditionally governments but also increasingly corporations. The social movement theory has been applied to corporations facing stakeholder collective action (King 2008), NGO activism (den Hond \& de Bakker 2013), and stakeholder alliances (Fassin et al. 2016), among others. While the theory has not been applied to corporations as social movement actors, the growing activist role of brands makes it relevant and appropriate. In particular, mobilizing structures and political opportunities are of relevance here.

Mobilizing structures are the "collective vehicles, informal as well as formal, through which people mobilize and engage in collective action" (McAdam et al. 1996: 3). Mobilizing structures can be formal organizations or informal networks that facilitate collective action through providing a resource base, an arena for interaction thereby helping overcome the high starting cost (King 2008). This is relevant to the collection action of corporate actors as well; brands also need some kind of mobilizing structures to coordinate them and solve collective action problems.

Political opportunities refer to the broader political environment that shapes opportunities and poses external constraints for social movements (Tarrow 1998, Tilly 1978). The degree of mobilization is likely to depend on the perceived opportunities in terms of political openings: favourable signals embolden social movements while unfavourable ones dampen their collective action (Tarrow 1998, Meyer \& Minkoff 2004). On the other hand, the level of influence a movement can exert over the outcome is mediated by political contexts (Amenta 2006). Notably, the level of democratization and the nature of regime importantly affect the movement's influence on the outcome (Tilly 1999). Hence, brands' collective action is 
constrained as well as enabled by political opportunities whereas their influence on state is shaped by political contexts.

Resource dependence

According to Keck \& Sikkink (1998: 29), the target's vulnerability stems from "the availability of leverage and the target's sensitivity to leverage". This aspect is well-captured by the resource dependence theory. Pfeffer \& Salancik (1978: 51) define dependence as "the product of the importance of a given input or output to the organization and the extent to which it is controlled by a relatively few organizations". When the resource exchange is not equally important to both parties, the relationship becomes that of asymmetry, giving power to the less dependent party and allowing them to influence the behaviour of the more dependent one (Ibid.: 53). While the resource dependence theory was originally developed for inter and intra-organizational relationships, it has been widely applied to the CSR literature examining firm-stakeholder relationships (Frynas \& Yamahaki 2016). Beyond its wellrecognized application to firms' relationships with stakeholders (Frooman 1999, Julian et al. 2008, den Hond et al. 2015), the resource dependence theory has relevance to firm-state relationships as well, especially in developing countries where firms are politically dependent on government for various resources (Gao \& Hafsi 2017).

When state is the ultimate target of boomerang campaigns, resources at stake can be financial (e.g. aid, trade, loans), military, or legitimacy (den Hond \& de Bakker 2012). While some of these resource exchanges exist mainly between states (e.g. military), others can occur between states and corporations. Based on the Myanmar divestment case, den Hond \& de Bakker (2012) conclude that the balance of power is tilted toward the state, since the state has concessions and orders to grant whereas firms face competition to win them. This is not always the case, however. In non-extractive industries, developing country governments go 
extra lengths to entice foreign investment, providing tax and other incentives. When the exchange is not equally critical to the firms, as they can freely choose investment locations for instance, the relationship can be asymmetric, making the state more dependent on the firms.

Figure 4 summarizes the three-stage model of firms' response, collective action and influence based on the above discussion. In the first phase, brands act upon issue salience in terms of impact on their images and performance. Subsequently, mobilization structures consisting of formal organizations and informal networks affect the extent of collective action. The likelihood of firms' collective action is also shaped by perceived political opportunities. Lastly, firms' influence on state policy and action is mediated by the political context and the nature of resource dependence between the state and the firms.

\section{---Figure 4 about here---}

\section{Context and Method}

To study a brand-to-state boomerang pattern and brand advocacy more in general, the most important criterion for case selection is the sheer presence of brands' political engagement. In the last few years, Cambodia counts at least three incidents of brand advocacy surrounding the crackdown in 2014, minimum wage negotiations in 2015, and the trade union law in 2016, making it a fertile ground to study brand advocacy. ${ }^{1}$

Demands for external alliances and interventions arise when civil society actors face a recalcitrant domestic government (Keck \& Sikkink 1998). Democracy in Cambodia remains severely flawed despite periodic elections, making it "electoral authoritarianism" (McCargo 2005, Hughes \& Un 2013). The Cambodian People's Party (CPP) led by Hun Sen has consolidated power over the past two decades, shunning oppositions outside and within the party. Hughes \& Un (2013: 10) describe the regime as “...authoritarian, corrupt, and based heavily upon neo-patrimonial institutions, whose survival and expansion represent key 
interests driving, and limiting, public policy". Labour under this regime is framed "as a commodity to serve the political and wealth accumulation interests of ruling elites, but also as a problem to be managed through semi-authoritarian modes of governance aiming to maintain order and stability" (Ward \& Mouyly 2015: 261).

Anner (2015) argues workers are likely to resort to cross-border solidarity campaigns when labour is controlled by repressive employers. In Cambodia, labour (independent union movement in particular) is repressed by the state and employers with threats of legal actions and physical intimidation (Arnold 2014). About 95 percent of exporting garment factories are owned by foreign investors, most of whom are overseas Chinese, and they are cohesively organized through the Garment Manufacturers Association of Cambodia (GMAC), rendering their collective action effective (Ear 2013). In the aftermath of the violent crackdown, the GMAC not only threw support for the military intervention but also encouraged filing lawsuits against six independent union federations for inciting violence and inflicting damage on their properties. Such repressive approach of the state and employers drives labour activists to seek external alliances and interventions.

Brand advocacy requires the presence of brands willing to assume a political role vis-à-vis government. Cambodia has a long and rich history of brands' engagement given the ILO's presence. The ILO monitoring programme, which grew out of the 1999 US-Cambodia Textile and Garment Trade Agreement, was renamed as Better Factories Cambodia (BFC) in 2005 and served as the blueprint for the Better Work programme (Oka 2014). On numerous occasions, BFC has served as a forum for brands to engage and collaborate with each other as well as with other stakeholders (Ibid.).

Furthermore, the garment industry needs to account for an important part of the economy for a group of brands to wield influence. In Cambodia, garment export accounts for about $15 \%$ of GDP and $85 \%$ of the country's export, and nearly $90 \%$ of Cambodia's garment 
export is sourced by brands and retailers from Europe and the US (Ministry of Commerce). For instance, Gap and H\&M are some of the most important buyers sourcing from Cambodia. Thus, European and American brands hold important leverage not only vis-à-vis supplier factories but also in relation to the Cambodian government. While such high degree of dependence on foreign brands is also seen in other garment producing countries such as Bangladesh and Jordan, it is unlikely in large countries such as in China and Indonesia that do not depend on a single industry. In sum, these conditions in the Cambodian garment industry make it a rich experimental ground for brands' political engagement and collective action.

Although this qualitative research focuses on events in one country, it is not a single-case study, as it examines three episodes of brand advocacy. These three incidents can be considered as "within-case observations" providing "within-case variation" (Gerring 2007: 19-21) to illustrate the contours of brand advocacy. By focusing on within-case analysis and holding the macro institutional context more or less constant, it enables us to delve into other fine-grained factors that enable or hinder brand advocacy vis-à-vis government.

This study is based on qualitative analysis of local newspaper articles as well as interviews of key individuals closely involved in the events. The author systematically searched two daily newspapers (the Daily Cambodia and the Phnom Penh Post) that closely follow developments in Cambodia's garment industry. In total, 138 relevant articles were retrieved for the period between November 2014 and June 2016. In addition, twelve interviews were conducted during 2016-17 with four labour activists (of which three based in Cambodia and one in the US), five representative of international brands (of which two headquartered in Germany, two in the UK, and one in the US), one advisor to the Cambodian government, one former official of an intergovernmental organization, and one representative of a multistakeholder initiative. ${ }^{2}$ All the interviewees were closely involved in at least one and mostly all of the episodes under investigation. Given the sensitive nature of the topic, the 
interviewees were assured anonymity. All the interviews except one were recorded, transcribed, and analysed.

Figure 5 summarizes the iterative process of data collection and analysis, inspired by Egels-Zandén et al. (2015). In the first instance, the newspaper articles were used to understand and describe the chronological development of the three episodes and to identify key actors. Subsequently, document analysis was conducted to identify important themes or first-order description surrounding the three events. Based on this initial analysis, interview questions were devised to delve deeper into the processes and mechanisms. Structured interviews covered the role of the interviewees and other key actors in each episode, their views on why and when brands collectively lobbied the government, as well as broader opportunities and challenges for brands' role in promoting labour rights and living wages. The interview data helped refine the initial themes while adding new ones.

The analysis of the interview data revealed three distinct phases in each case: brands' initial responses to the event, presence or absence of collective action, and their influence on the government. Through coding process, it became apparent that different issue characteristics led to variable responses by brands. Moreover, interview data pointed to the importance of some kind of coordinating mechanisms, both organizational and interpersonal, in nurturing coherence and helping overcome brands' collective action problems. Ultimately though, the level of influence brands exert on the government hinged upon the political context and power asymmetry between the government and brands. These identified themes were initially labelled as issue characteristics, coordinating mechanisms, political context, and power asymmetry. These categories were further refined based on the theories of issue salience, social movements, and resource dependence to yield the conceptual framework provided earlier. The next section examines the three cases based on the three-stage model of firms' response, collective action, and influence. 


\section{Violent Crackdown}

As shown in the opening, several days of nationwide strikes organized by independent union federations ended violently as the military police shot at stone throwing striking garment workers on the $3^{\text {rd }}$ of January 2014, leaving five dead and wounding more than thirty. Moreover, 23 independent union leaders and workers were detained without trial for months. This deadly incident widely covered by the international media provoked public outcries and calls to release the detained activists.

\section{Brand Response}

Faced with the deadly violence in one of their key supply bases, brands saw an urgent need to intervene. A former official of an intergovernmental organization recalls: "buyers started really freaking out...we had so many buyers calling us saying 'what shall we do?"' Violent repression arouses strong feelings among the public and tarnishes brands' images. As an independent union federation leader put it, “customers in the West don't want to buy t-shirts with workers' blood on it” (Kasztelan 2014).

It was not only brands' images but also their smooth operation that came under pressure as the widespread unrest disrupted production on a large scale. The GMAC estimates the cost of strike to be $\$ 200$ million in lost sales. The Chairman of the GMAC said "risky business" is what high street brands don't like, worrying that brands may stop sourcing from Cambodia because of future strikes (Kasztelan 2014). Given the fast-moving nature of the industry subject to fleeting trends, disruption to production leading to late (or no) deliveries is likely to hit brands' sales and performance. One brand representative explains, 
When all the riots happened in Cambodia, there's no point in not paying those people, if there's no product, you're not going to make any profit anyway. So, stability is now part and parcel of where the brands are looking.

Thus, brands perceived the crackdown as undoubtedly highly salient both in terms of their images and operations. Initial reactions do not automatically translate to collective action and influence, however.

\section{Brand Collective Action}

Just a few days after the incident, a group of seven brands took initiative to write a letter condemning violence. The letter was signed by Adidas, Columbia, Gap, H\&M, Inditex, Levi, and Puma. A representative of one of the signatory brands recounts, "We, through our close network, agreed to write a letter...because of the extreme nature of what they've done. So, that action was done very quickly". Such spontaneous and swift collective action was made possible by the pre-existing interpersonal network. "Cambodia has a long history of engagement because of the Better Work Programme. Many of the brands in the compliance area know each other very well, regularly in communication with each other", explains the brand representative

Nonetheless, the initial letter did not attract a large mass of brands. According to a former official, collaboration on a larger scale was hampered by brand rivalry. "So that didn't get a lot of traction". As a neutral broker, BFC took initiative to coordinate buyers to agree on a common text for a joint letter. In late January, 27 international buyers and three global union federations sent a joint letter to the Prime Minister, expressing "grave concern" over the fatal shooting, demanding immediate investigation into the killings and the release of detained activists and workers. The signatory buyers made up about 85 percent of Cambodia's export, according to one estimate (Teehan 2014). 
The first joint letter was followed up by a visit of brand representatives. "By then, there were a lot of letters sent from the buyers to the government. So the group decided that it had to be followed up at least by a visit and it should be part of the ongoing dialogue", recounts a former official. During the first visit, "they (brands) were pleasantly surprised when there were several ministers and it wasn't just hand shaking and meaningless". Nonetheless, the government continued to detain activists even after the first visit.

In May 2014, the same group of 30 international buyers and union federations issued a second joint statement saying that "due to reaction of consumers and the disruptions to production and shipping caused by continued unrest, Cambodia was at risk of losing its status as a strategic sourcing market" (Phorn \& Zsombor 2014). This statement makes it clear that brands are concerned about the incident's impact on their images (reaction of consumers) and operations (disruptions to production). From the second letter and visit, the Ethical Trading Initiative (ETI), a UK multi-stakeholder initiative took over the coordinating role from BFC.

\section{Brand influence}

While several joint letters were sent and meetings organized, what proved decisive appears to be a credible threat of brands withdrawing from Cambodia. The representative who led the buyer delegation recounts as follows:

But we didn't do it saying unless you do this, we're going to pull out. But actually one of the... jeans companies ... said last year we bought two million pairs of jeans; this year we're buying half a million pairs. You saw the instant change.

Labour activists confirm the immediate impact as the detained activists were released a few days after Levi's communicated its withdraw of orders. In addition to Levi's, H\&M made clear its intention of reducing orders from Cambodia, following campaigns and protests organized by labour activists in front of H\&M shops in the US and Sweden. Nonetheless, a brand representative knowledgeable about the local politics cautions against directly 
attributing the government decision to one brand's action, given multiple voices denouncing the crackdown.

In terms of political opportunity, the crackdown occurred against the backdrop of political tensions and contestations. The minimum wage strikes formed part of a broader protest movement led by the opposition Cambodian National Rescue Party (CNRP) and joined by different streams of protesters, demanding the resignation of the Prime Minister, fresh elections, and higher wages among others. Threatened by the convergence of discounted forces, the government ordered military police to intervene. While the regime was certainly not opening, it was coming under stress.

Sustained international pressure and credible threats by brands prompted the Cambodian government to release 23 independent union leaders and workers detained for months without trial. Nonetheless, six leaders of independent union federations have been charged for inciting violence and they remain under judicial supervision, restricting their right to organize and campaign. Moreover, there has been no genuine investigation into the killing and no official compensation made to the people died.

In sum, this episode illustrates the conceptual framework and underscores key factors. First, issue salience both in terms of image and performance prompted brands to act swiftly. Second, mobilization structures, both in terms of informal network and formal organizations (i.e. BFC and the ETI) played important roles in coordinating brands and facilitating their collective action. Third, political context was more fluid and unstable in the aftermath of the mass protests. Above all, what proved decisive for brand influence appears to be their credible threat to withdraw from Cambodia.

\section{Minimum wage negotiations}


The protests that led to the deadly crackdown in January 2014 centred on the minimum wage deal hammered out by the government in December 2013. While independent unions demanded $\$ 160$ per month (double the $\$ 80$ minimum wage rate back then), the government unilaterally set the garment industry's 2014 minimum wage initially at $\$ 95$ and then at $\$ 100$. Unions rebuffed it and workers continued to strike and protest en masse, which abruptly ended in violence. The minimum wage negotiations continued against the backdrop of fear and heightened security, and in November 2014, after rounds of negotiations with the industry and union representatives, the government decided \$128 as the minimum wage for 2015 .

\section{Brand Response}

During the run-up to the minimum wage negotiation in 2014, brands came under mounting pressure from organized labour, both local and global, to take responsibility for what they call "starvation wages". In the autumn of 2014, minimum wage hike campaigns shifted its target from the Cambodian government and garment factories to brands. Rallying workers started carrying banners saying "Gap starves Cambodian workers" and the like (Pech \& Teehan 2014). Union federations delivered strongly worded petitions to local offices of brands such as $\mathrm{H} \& \mathrm{M}, \mathrm{C} \& \mathrm{~A}$, and $\mathrm{M} \& \mathrm{~S}$. This local action was supported by their international solidarity networks on "Global Days of Action", as IndustriALL, Service Employees International Union (SEIU) and North American Labor Union Workers United organized protests in front of the brands' shops (e.g. Gap, H\&M) in multiple countries calling for a minimum wage increase (Teehan et al. 2014).

Strong local mobilization coordinated with global campaigns led by GUFs enhanced issue salience for the targeted brands as their images came under pressure. Nonetheless, issue salience was not as heightened as in the case of repression: violence clearly threatens brands' images and disrupts operations, whereas wages have mixed implications on performance. 
Indeed, higher wages are not necessarily compatible with the business models of brands sourcing from Cambodia often based on low costs. Such mixed implications for firm performance explain why brands did not react in a concerted and determined manner as in the aftermath of the crackdown.

\section{Brand Collective Action}

While brands are traditionally unwilling to discuss distributive issues, a few brands sourcing from Cambodia expressed their willingness to increase the price they pay. Just one day after the first Global Day of Action and weeks before the minimum wage decision, eight major brands and retailers (i.e. C\&A, H\&M, Inditex, Primark, Next, New Look, N Brown Group and Tchibo) wrote to the Cambodian government and GMAC pledging that they would pay more for Cambodian-made garments if workers were to be paid more. Specifically, the letter says "As responsible business our purchasing practices will enable the payment of a fair living wage and increased wages will be reflected in our FOB prices" (Sourcing Journal 2014).

This was an unprecedented move of major brands coming together and promising in writing they would adjust the cost of the supply chain to reflect higher wages. While H\&M had experimented with a living wage pilot project in Cambodia, its web statement says that "A collaborative approach is crucial and that is why we today, together with other brands, have sent a letter to the Cambodian government and the GMAC to clarify our shared position and intention in the upcoming wage negotiations in Cambodia (Sourcing Journal 2014)". It is clear from this $\mathrm{H} \& \mathrm{M}$ statement that the pledge was aimed at influencing the government decision.

It is worth noting that all the eight brands that made pledge are ETI members. While it was not the ETI itself that coordinated this particular action, it was enabled by a closely knit community of ETI brands, according to one brand representative. As for the ILO, not just 
BFC but also the ILO country office based in Bangkok actively promoted higher minimum wages and urged global buyers to pay more. Not only did the ILO issued statements calling on all buyers to pay more but also provided technical expertise showing brands concretely how much they needed to pay more to accommodate the minimum wage rise. ${ }^{3}$

Nevertheless, the vast majority of brands did not join in making the pledge. Notably, key US names (e.g. Gap, Levi's, Walmart) were missing. Labour activists and experts concur that European buyers in general are more progressive and easy to work with compared to American buyers, who tend to shun anything that can be legally binding.

\section{Brand influence}

While the minimum wage still lags behind a living wage, it made great strides in just two years from $\$ 80$ to $\$ 128$, which further rose to $\$ 140$ in 2016 despite vehement opposition from the GMAC. While it is difficult to ascertain the level of influence the brand pledge had on the government decision, it appears to be mixed at best. One labour activist says the brand pledge that came just before the government decision had some impact, while the former official says it did not really have an impact because buyers did not follow through.

Even if the initial brand pledge had some impact on the government decision, subsequent pledges of similar nature are likely to have lost credibility, given that the promise of higher prices remains largely unfulfilled. 99 percent of the GMAC member factories surveyed in late 2015 reportedly received the same prices from their buyers as the year before or less (Zsombor 2015). A local labour activist and a Cambodian government official call brands' action "propaganda", as almost all brands have failed to deliver on their promise.

A more probable cause for the substantial wage hike was the mass mobilization that threatened the regime and obliged the government to placate workers, opening a crack in the political opportunity structure. As a former official recounts, "There was that huge rally led 
by CNRP and workers. That really scared the government...for the wage increase, that made a difference".

In sum, this episode shows the importance of issue salience in getting brands to respond. Even when the mobilization structures (i.e. informal network, the ILO) were well in place, the mixed implications of wage increases on firm performance meant that only a handful of brands were willing to make pledge and even fewer actually made good on the pledge. Moreover, the episode shows that brand influence is mediated by the political context and mobilization of other actors, notably workers and unions at the local as well as the global levels.

\section{Trade Union Law}

In Cambodia, the trade union law setting out rules for forming, running, and dissolving unions has been in preparation for nearly a decade. During 2011-13, the draft went through rounds of revisions with significant inputs from civil society actors, dropping most of the provisions deemed unacceptable by labour activists and the ILO. In the run-up to the 2013 election, however, the Cambodian government shelved the draft law, preferring to avoid controversy. In 2014, the trade union law was suddenly revived following the violent crackdown. To the surprise of unions and NGOs, the revived version ignored the rounds of revisions undertaken.

The government re-inserted anti-union provisions, made few concessions, and rushed to pass the trade union law in April 2016. Despite vehement opposition from independent unions, the government remained adamant on the strike threshold, requiring support from just over half of union members to call a legal strike. The government also remained firm on eligibility criteria for union leaders (i.e. lack of any criminal charges), deemed to conflict with the ILO conventions. Perhaps most alarmingly, the law gives the court power to dissolve unions if any 
one of its leaders is found to violate the law. As one labour activist puts it, "The ability to dissolve unions is insanity. They (the government) can dissolve anything that they want for any reasons that they want".

\section{Brand Response}

Only a few brands responded prior to the forceful passage of the revised trade union law. As the revived draft union law was circulated very late in the process and key independent union federation leaders were handicapped by the pending charges, there was little mobilization on the part of workers and unions. One union organizer describes as follows:

The government was very smart in the sense that they didn't allow any drafts to go around. So nobody knew the actual contents of the law. There were no public consultations... The strategy of the government was to alienate various union leaders who had charges pending.

International social actors notably Clean Clothes Campaign (CCC), the International Trade Union Confederation (ITUC) and IndustriALL tried to engage international brands. ITUC made public detailed comments sent to the Cambodian government clearly outlining problematic articles of the draft union law. During the parliamentary debate on the trade union law, CCC together with other labour activist organizations issued an open letter to all brands sourcing from Cambodia, urging them to issue a public support statement for a trade union law fully respecting the ILO conventions "as a condition for future sourcing from the country" (CCC 2016).

Most brands remained silent as the trade union law passed the National Assembly in April 2016. This relative silence and lack of interest among brands stood in stark contrast to the aftermath of the crackdown. One CCC coordinator said "we are really puzzled as to why they [brands] are so quiet on this issue that will affect workers all over the country-taking into consideration they have been talking loudly on other issues like higher wages for garment 
workers" (Baliga et al. 2016). This can be explained by the nature of issue as one brand representative explains:

When it comes to law...At the government affairs [department] level, they go, do we really want to write a letter about the trade union law to the government? The government affairs' person may say, it's not really critical for us to have a voice on this topic.

\section{Brand Collective Action}

For the trade union law, there was no collective action of brands but only sporadic individual responses. In response to the call from NGOs and unions, four brands (i.e. Levi's, H\&M, Inditex, Primark) separately issued public statements in support of a trade union law that respects ILO conventions, but these public statements came in too late in the process and did not mention whether and how the law would affect their sourcing decisions.

In this episode, there was no formal mobilization structure to coordinate or facilitate brands' collective action. Although the ILO was described as a facilitator in the other two cases, all the local labour activists interviewed criticized the ILO for taking the side of the government by working secretively with them and not releasing the drafts before it was too late.

The degree of mobilization is also affected by the political opportunities perceived by brands. Just like social movement organizations, brands seem to calculate the likelihood of success and act when their actions are likely to have an impact given the circumstances. One brand representative explains that few brands took action because they knew their voice would not be heeded:

We all know that the driver of that trade union law was a very much domestic issue. Domestic political issue. And we weren't going to change that. We cannot change the make-up of the power structure in Cambodia.

Brand Influence 
The question is whether the outcome would have been different, had more brands been mobilized. Although we cannot answer this counter-factual question with a high degree of certainty, it is reasonable to conjecture that the government would not have made much concession given the political context. This time more than ever, the government was determined to tighten the grip on civil society, notably vocal independent union federations and NGOs. According to one union organizer,

In its analysis of why the election in 2013 was so close or perhaps why they [the ruling party] even lost it, they determined that they wanted not only to attack the opposition but also to attack the civil society, limit, and constrain it... The trade union law is not about labour relations but a way to control independent union movement.

While there were minor openings right after the mass demonstrations followed by the crackdown, by the time the trade union law was passed, the ruling party had quelled the opposition and repressed the civil society, closing windows of opportunity.

In sum, this episode illustrates the limit of leveraging brands when issue salience is limited and the political context is unfavourable. Limited mobilization of workers and lack of immediacy felt by brands meant that few brands were willing to act. Moreover, brand leverage is not a panacea in the face of a government determined to stifle any countervailing power.

\section{Discussion}

In Cambodia, brand advocacy had a major impact on releasing the detained activists, a minor influence on the minimum wage increase, and no influence on the trade union law. Table 1 summarizes the three cases according to the three-stage model. When the issue has immediacy, involving extreme violence or tragic events, more brands are compelled to respond. When the issue has mixed implications on firm performance as in the case of a 
minimum wage hike, fewer brands respond. When the issue is not deemed sufficiently salient (i.e. trade union law), even fewer brands respond.

---Insert Table 1 about here---

The extent to which brands act collectively also depends on mobilization structures, both formal coordinating organizations and informal networks. Cambodia's garment industry has become an experimental ground for brand advocacy because of the ILO programme that brought together a group of brands to collaborate. The ETI also played a key role in creating a core of committed brands through regular meetings and exchanges. Such credible organizations assuming coordinating roles facilitate collective action of a larger number of brands. Through these collaborative platforms, brand representatives have come to form informal networks, enabling more spontaneous collective action.

Furthermore, brands' mobilization and influence are circumscribed by political opportunities and contexts on the ground. The mass mobilization of workers and the convergence of opposition forces shook the regime and created political openings, providing opportunities for brands to intervene in helping release detained activists and raise the minimum wage. By the time the government mooted the trade union law, however, the regime had stifled the opposition and consolidated power, dampening brands' prospects for influencing the government.

Ultimately, the level of influence brands can exert on the government hinges upon the degree of leverage brands are willing to exercise and the country's dependence on brands. In the aftermath of the crackdown, one brand withdrew orders while multiple brands made explicit their intentions to reconsider sourcing from Cambodia, signalling a credible threat. This is arguably the most important leverage brands have vis-à-vis producer governments. For minimum wage negotiations, a group of eight brands made pledge to increase the price they 
pay to factories (though few made good on the pledge). As for the trade union law, none of the brands that wrote letters made an explicit link to their sourcing decisions.

Overall, the three cases examined above illustrate and support the conceptual framework, which posits that brands' action and influence are contingent upon issue salience, mobilization structures, political opportunities/contexts, and resource dependence. Although brand advocacy vis-à-vis government has potential to effect more broad-based changes than the supply chain-specific CSR approach or brand-to-supplier boomerang, the chances of satisfying these conditions may be slim. Moreover, we need to be cautious not to overestimate brand influence and underestimate worker agency; the massive mobilization of workers was critical to making the government receptive to raise minimum wages. As Amengual and Chirot (2016) show in their study of transnational and state labour regulation in Indonesia, worker mobilization targeting the state creates public contestation and prompts the state to take pro-labour actions.

\section{Conclusion}

Given the inherent limitations of the CSR approach to labour in global supply chains, scholars increasingly call for a combination of public, private, and social forces to improve labour conditions in global supply chains (Locke 2013, Donaghey et al. 2014; Gereffi \& Lee 2014). Nonetheless, we still know little about the conditions, processes, as well as the impact of such confluence of forces on labour rights and conditions beyond the factory-level. This paper has addressed this gap by focusing on a new breed of brand boomerang (brand-to-state boomerang), developing a conceptual framework for brand advocacy, and examining the conditions under which brands come together to lobby government in favour of better rights and conditions for workers. 
The study has shown both promise and limits of brand advocacy. On one hand, brand advocacy can address sector-wide issues that cannot be dealt with by the CSR approach of individual brands. When the level of issue salience is high, impacting brand images and firm performance, brands are likely to act in a concerted and determined manner, as we saw after the crackdown. On the other hand, brand advocacy faces severe constraints when issue salience is limited and political opportunities/contexts are unfavourable, as in the case of the trade union law. Indeed, when the government is determined to stay in power and to stifle any independent or opposition movements, even powerful brands have difficulty making their voices heard.

This article makes important contributions to the literature on labour in global supply chains. Empirically, this is one of the first studies examining the advocacy role of brands in promoting labour rights and conditions vis-à-vis a producer country government. On the theoretical front, this study contributes a typology of boomerang politics and develops a testable conceptual framework specifying the conditions under which brands are likely to respond, act collectively, and influence government for pro-worker change. While this article does not explicitly test the propositions given the limited cases, future studies can test and refine the framework based on broader empirical evidence.

Moreover, this study has broader implications on the literature on corporations and activism (den Hond \& de Bakker 2007, Yaziji \& Doh 2009, den Hond et al. 2015). Recently, there is growing interest in "corporate-sponsored activism" or an activist role of corporations (e.g. Walker and Rea 2014, McDonnell 2015). Yet, corporate advocacy vis-à-vis host country government in favour of pro-worker change has attracted little scholarly attention so far. By casting corporations as social movement actors rather than simple targets and showing the relevance of social movement theory to the study of corporate activism, this study offers fresh empirical and theoretical insights to the literature. 
One of the limitations of this study is that the phenomenon studied is limited to one industry in one country. The global garment industry represents one of the most exposed and scrutinized industries, shaped by more than two decades of contestation among various actors (Bartley 2007). This makes garment brands more sensitive to labour issues in global supply chains, compared to firms in other industries. Although Cambodia's history of brands' engagement and susceptibility to brand pressure make it somewhat unique, the phenomenon of brand advocacy is spreading in other countries. In Bangladesh, a group of brands threatened to boycott the Dhaka apparel summit in February 2017 in response to the government crackdown on striking workers demanding higher wages. Moreover, a group of brands have spearheaded Action, Collaboration and Transformation (ACT) initiative to promote industry-level collective bargaining in several garment producing countries (Alexander et al. 2017). This involves brands advocating industry-level collective bargaining vis-à-vis host country governments; another indication that brand advocacy is becoming more common and important. By shedding light on the hitherto neglected advocacy role of brands in producer countries, this study seeks to open up a new research agenda. 
1. There were examples of brand advocacy prior to this. As early as in 2005, a group of brands played a key role in pressuring the Cambodian government to release five detained activists (Ear 2013).

2. One interview was conducted via email communication. Two of the twelve interviews were undertaken as part of the Garment Supply Chain Governance Project (www.garmentgov.de), and I thank the collaborators for allowing me to use quotes from the two interviews.

3. The ILO estimates showed that supporting the new minimum wage of USD 128 would require global brands to increase the prices they pay to Cambodian factories by up to 3.0 percent (ILO 2015).

\section{Acknowledgements}

This article has benefitted from the data collected for the Garment Supply Chain Governance Project funded by the Volkswagen Foundation (grant no. 90807). I thank the interviewees for generously sharing their time and insights. I also thank Niklas Egels-Zandén, Dima Jamali and anonymous reviewers for helpful comments on the drafts of this paper. 
Figure1. State-to-state boomerang

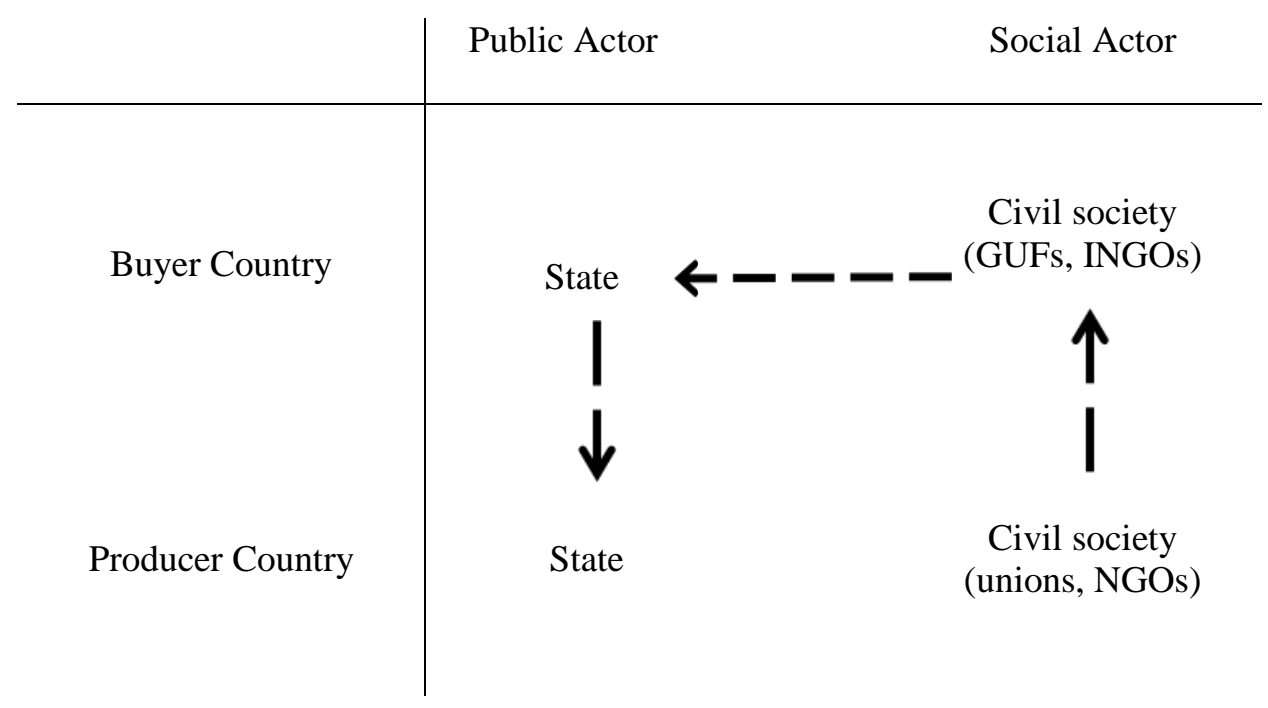

Figure 2. Brand-to-supplier boomerang

\begin{tabular}{l|cc} 
& Private Actor & Social Actor \\
\hline Buyer Country & Brand & $\begin{array}{c}\text { Civil society } \\
\text { (GUFs, INGOs) }\end{array}$ \\
Producer Country & Supplier firm & Civil society \\
(unions, NGOs)
\end{tabular}


Figure 3 Brand-to-state boomerang

\begin{tabular}{l|cc} 
& $\begin{array}{c}\text { Private/Public } \\
\text { Actor }\end{array}$ & Social Actor \\
\hline Buyer Country & Brand & Civil society \\
Producer Country & State & Civil society \\
(unions, NGOs)
\end{tabular}

Figure 4. Three-stage model of firms' response, collective action, and influence
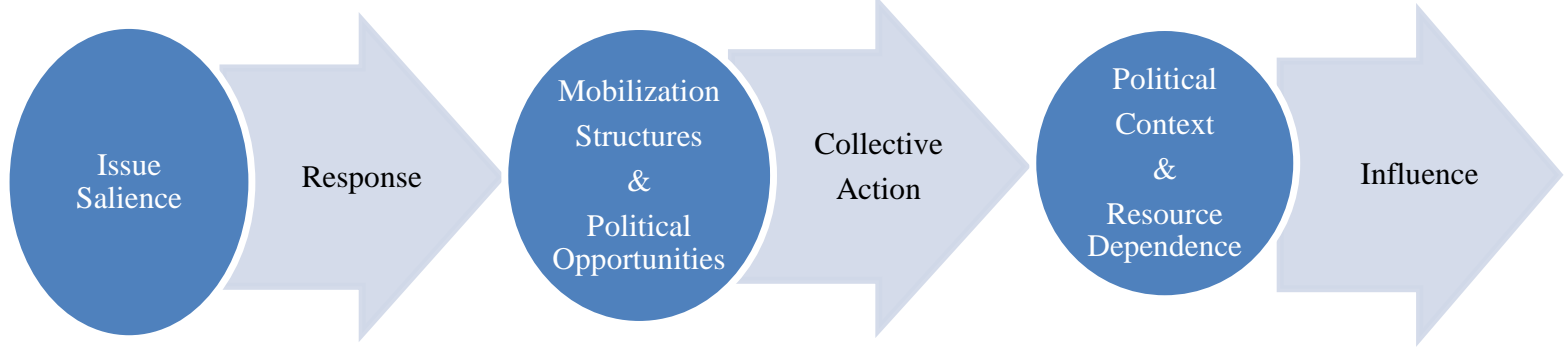

Figure 5. Process of data collection and analysis

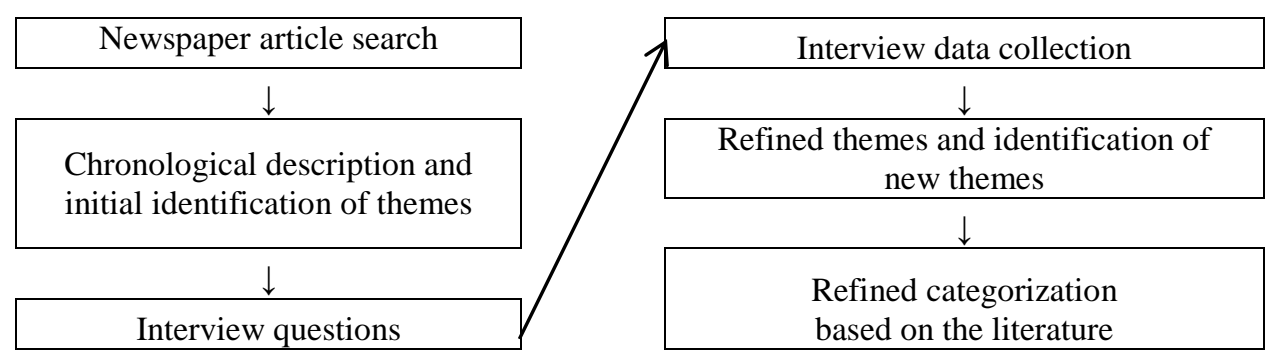


Table 1. Summary of the three cases based on the three-stage model

\begin{tabular}{|c|c|c|c|c|c|c|c|}
\hline & Case & $\begin{array}{c}\text { Issue } \\
\text { Salience }\end{array}$ & Response & $\begin{array}{c}\text { Mobilization } \\
\text { Structure }\end{array}$ & Collective Action & $\begin{array}{c}\text { Political Opportunity/ } \\
\text { Context }\end{array}$ & Outcome (Influence) \\
\hline $\mathrm{I}$ & Crackdown & High & $\begin{array}{l}\text { Immediate and } \\
\text { concerted }\end{array}$ & ILO, ETI & $\begin{array}{c}\text { Collective and } \\
\text { credible threat } \\
\text { (27 brands) }\end{array}$ & Regime instability & $\begin{array}{l}\text { Release of detained activists } \\
\text { (major influence) }\end{array}$ \\
\hline II & Minimum wage & Medium & Variable & ILO, ETI & $\begin{array}{l}\text { Collective pledge } \\
\text { ( } 8 \text { brands) }\end{array}$ & Regime instability & $\begin{array}{l}\text { Substantial minimum wage increase } \\
\text { (minor influence) }\end{array}$ \\
\hline III & Trade union law & Low & Mostly silent & --- & $\begin{array}{l}\text { Individual statements } \\
\qquad(4 \text { brands })\end{array}$ & Regime consolidation & $\begin{array}{l}\text { Forceful adoption of law undermining FoA } \\
\text { (no influence) }\end{array}$ \\
\hline
\end{tabular}




\section{References}

Alexander, R., Ashwin, S., Lohmeyer, N., Oka, C. and, Schüßler, E. 2017. 'Analysing the evolving texture of transnational industrial relations: Opening the black box of interfirm and firm-union relationships in the global garment industry'. Garment Supply Chain Governance Discussion Paper Series No. 01/2017. http://www.wiwiss.fuberlin.de/forschung/Garments/Publications/index.html

Amengual, M. 2010. 'Complementary labor regulation: the uncoordinated combination of state and private regulators in the Dominican Republic'. World Development, 38: 405-414.

Amengual, M. and Chirotm L. 2016. 'Reinforcing the state: Transnational and state labor regulation in Indonesia'. Industrial and Labor Relations Review, 69, 5, 1056-1080.

Amenta, E. 2006. When Movements Matter: The Townsend Plan and the Rise of Social Security. Princeton, NJ: Princeton University Press.

Anner, M. 2012. 'Corporate social responsibility and freedom of association rights: the precarious quest for legitimacy and control in global supply chains'. Politics \& Society, 40:4, 609-644.

Anner, M. 2013. 'Workers' power in global value chains: Fighting sweatshop practices at Russell, Nike and Knights Apparel', In Fairbrother, P., Hennebert, M., and Levesque, C. (Eds.), Transnational Trade Unionism: New Capabilities and Prospects: 23-41. London: Routledge

Anner, M. 2015. 'Worker resistance in global supply chains: Wildcat strikes, international accords, and transnational campaigns', International Journal of Labour Research, 7: 1-2, 17-34. 
Armbruster-Sandoval, R. 2005. Globalization and Cross-border Labour Solidarity in the Americas. New York: Routledge.

Arnold, D. 2014. 'Workers' agency on power relations in Cambodia's garment industry'. In Rossi, A., Luinstra, A. and Pickles, J. (Eds.), Towards Better Work: Understanding Labour in Apparel Global Value Chains: 212-231. Basingstoke: Palgrave Macmillan.

Baliga, A., David, S. and de Cartelet, D. 2016. 'Labouring to understand'. The Phnom Penh Post, 1 April 2016.

Barrientos, S. and Smith, S. 2007. 'Do workers benefit from ethical trade? Assessing codes of labour practice in global production systems'. Third World Quarterly, 28: 4, 713-729.

Bartley, T. 2007. 'Institutional emergence in an era of globalization: the rise of transnational private regulation of labor and environmental conditions'. American Journal of Sociology, $113: 2,297-351$.

Bartley. T. and Egels-Zandén, N. 2015. 'Responsibility and neglect in global production networks: the uneven significance of codes of conduct in Indonesian factories. Global Networks, 15:1, 21-44.

Bartley, T. and Egels-Zandén, N. 2016. 'Beyond decoupling: Unions and the leveraging of corporate social responsibility in Indonesia', Socio-Economic Review, 14:2, 231-255.

Bundy, J., Shropshire, C., and Buchholtz, A. 2013. 'Strategic cognition and issue salience: Toward and explanation of firm responsiveness to stakeholder concerns'. Academy of Management Review, 38: 3, 352-376.

Caraway, T. L. 2010. 'Labour standards and labour market flexibility in East Asia'. Studies in Comparative International Development, 45: 225-249. 
CCC (Clean Clothes Campaigns) (2016). Open letter to all brands sourcing from Cambodia. Available:https://cleanclothes.org/news/2016/03/22/open-letter-to-all-brands-sourcingfrom-cambodia Accessed on 1 February, 2017.

Coslovsky, S. and Locke, R. 2013. 'Parallel paths to enforcement: private compliance, public regulation, and labour standards in the Brazilian sugar sector'. Politics \& Society, 41: 497526.

Davis, G. F., McAdam, D., Scott, W. R. and Zald, M. N. (eds) 2005. Social movement and organizational theory. Cambridge: Cambridge University Press.

den Hond, F., and de Bakker, F. G. A., 2007. 'Ideologically motivated activism: How activist groups influence corporate social change'. Academy of Management Review, 32: 901-924.

den Hond, F., and de Bakker, F. G. A., 2012. 'Boomerang politics: How transnational stakeholders impact multinational corporations in the context of globalization'. In Lindgreen, A., Kotler, P., Vanhamme, J. and Maon, F. (Eds.), A Stakeholder Approach to Corporate Social Responsibility: Pressures, Conflicts, Reconciliation: 275-292. Aldershot: Gower Publishing.

den Hond, F. and de Bakker, F. 2013. 'Ideologically motivated activism: How activist groups influence corporate social change activities'. Academy of Management Review, 32, 3, 901924.

den Hond, F., de Bakker, F. and Doh, J. 2015. 'What prompts companies to collaboration with NGOs? Recent evidence from the Netherlands'. Business \& Society, 54: 2, 187-228.

den Hond, F., Stolwijk, S., and Merk, J. 2014. 'A strategic-interaction analysis of an urgent appeal system and its outcomes for garment workers'. Mobilization: An International Journal, 19: 1, 83-112. 
Distelhorst, G., Locke, R. M., Pal, T., \& Samel, H. 2015. Production goes global, compliance stays local: Private regulation in the global electronics industry. Regulation \& Governance, $9(3), 224-242$.

Donaghey, J., Reinecke, J., Niforou, C, and Lawson, B. 2014. 'From employment relations to consumption: balancing labour governance in global supply chains'. Human Resource Management, 53:2, 229-252.

Dutton, J. and Jackson, S. 1987. 'Categorizing strategic issues: Links to organizational action'. Academy of Management Review, 12, 76-90.

Ear, S. 2013. 'Growth in the rice and garment sectors'. In Hughes, C. and Un, K. (Eds.), Cambodia's Economic Transformation: 70-93. Copenhagen: NIAS Press.

Eesley, C. and Lenox, M. J. 2006. 'Firm response to secondary stakeholder action', Strategic Management Journal, 27, 765-781.

Egels-Zandén, N., Lindberg, K., and Hyllman, P. 2015. 'Multiple institutional logics: Private labor regulation in the Swedish Clean Clothes Campaign', Business Ethics: A European Review, 24, 347-360.

Egels-Zandén, N. and Merk, J. 2014. 'Private regulation and trade union rights: Why codes of conduct have limited impact on trade union rights'. Journal of Business Ethics, 123: 3, 461-473.

Fassin, Y., de Colle, S., and Freeman, E. R. 2016. 'Intra-stakeholder alliances in plant-closing decisions: A stakeholder theory approach'. Business Ethics: A European Review, 26, 97111. 
Frooman, J. 1999. 'Stakeholder influence strategies'. Academy of Management Review, 24: $191-205$

Frynas, J. and Yamahaki, C. 2016. 'Corporate social responsibility: Review and roadmap of theoretical perspectives'. Business Ethics: A European Review, 25, 258-285.

Gao, Y. and Hafsi, T. 2017. 'Political dependence, social scrutiny, and corporate philanthropy: Evidence from disaster relief', Business Ethics: A European Review, 26, 189-203.

Gereffi, G. and Lee, J. 2016. 'Economic and social upgrading in global value chains and industrial clusters: why governance matters'. Journal of Business Ethics, 133: 1, 25-38.

Gerring, J. 2007. Case Study Research: Principles and Practices. Cambridge: Cambridge University Press.

Heath, R. L. 1997. Strategic issue management: Organizations and public policy challenges. Thousand Oaks, CA: Sage

Hughes, C. and Un, K. 2013. Cambodia's Economic Transformation. Copenhagen: NIAS Press.

ILO. 2015. 'ILO calls on global garment buyers to help absorb Cambodia's new minimum wage'. Press Release issued by the ILO Country Office for Thailand, Cambodia, and Lao PD. 1 January, 2015.

Jamali, D., Lund-Thomsen, P., and Khara, N. 2017. 'CSR institutionalized myths in developing countries: An imminent threat of selective decoupling', Business \& Society, $56: 3,454-486$. 
Julian, S. D., Ofori-Dankwa, J. C. and Justis, R.T. 2008. 'Understanding strategic responses to interest group pressures'. Strategic Management Journal, 29: 9, 963-984.

Kasztelan, M. 2014. 'Striking a balance in Cambodia: International brands can no longer ignore human rights abuses in their supply chains'. The Diplomat, 11 January 2014

Keck, M. E. and Sikkink, K. 1998. Activists Beyond Borders: Advocacy Networks in International Politics. Ithaca, NY: Cornell University Press,.

Klein, N. 1999. No Logo: Taking Aim at the Brand Bullies. New York: Picador.

King, B. G. 2008. 'A social movement perspective of stakeholder collective action and influence'. Business \& Society, 47: 1, 21-49.

Lawrence, A. and Weber, J. 2014. Business and Society: Stakeholders, Ethics, and Public Policy. New York, NY: McGraw-Hill.

Locke, R. 2013. The Promise and Limits of Private Power: Promoting Labour Standards in a Global Economy. New York, NY: Cambridge University Press.

Locke, R., Rissing, B. A. and Pal, T. 2013. 'Complements or substitutes? Private codes, state regulation and the enforcement of labour standards in global supply chains'. British Journal of Industrial Relations, 51:3, 519-552.

McAdam, D., McCarthy, J. D., and Zald, M. N. 1996. 'Introduction: Opportunities, mobilizing structures, and framing processes-Toward a synthetic, comparative perspective on social movements'. In McAdam, D., McCarthy, J. D., and Zald, M. N. (Eds.), Comparative Perspectives in Social Movements: 1-20. New York: Cambridge University Press. 
McAteer, E. and Pulver, S. 2009. 'The corporate boomerang: Shareholder transnational advocacy networks targeting oil companies in the Ecuadorian Amazon'. Global Environmental Politics, 9, 1-29.

McCargo, D. 2005. 'Cambodia: getting away with authoritarianism?' Journal of Democracy, $16: 4,98-112$.

McDonnell, M. H. 2015. 'Radical repertoires: The incidence and impact of corporatesponsored social activism'. Organization Science, http://dx.doi.org/10.1287/orsc.2015.1017

Meyer, D. S., and Minkoff, D. C. 2004. 'Conceptualizing political opportunity', Social Forces, 82: $4,1457-1492$.

Oka, C. 2010. 'Accounting for the gaps in labour standard compliance: The case of Cambodia's garment sector'. European Journal of Development Research, 22(1): 59-78.

Oka, C. 2014. 'Evaluating a promising model of non-state labour regulation: The case of Cambodia's apparel sector'. In McCaan, D. et al. (ed.) Creative Labour Regulation: Indeterminacy and Protection in an Uncertain World, pp. 259-279. Palgrave Macmillan \& ILO.

Oka, C. 2016. 'Improving working conditions in garment supply chains: The role of unions in Cambodia”. British Journal of Industrial Relations, 54 (3): 647-672.

Pech, S. and Teehan, S. 2014. 'Thousands rally over wage'. The Phnom Penh Post, 13 October 2014.

Polaski, S. 2006. 'Combining global and local forces: the case of labour rights in Cambodia'. World Development, 34: 919-932. 
Pfeffer, J. and Salanik, G. R. 1978. The External Control of Organizations: A Resource Dependence Perspective. New York: Harper \& Row.

Phorn, B. and Zsombor, P. 2014. 'Global brands say unrest putting garment sector at risk'. The Cambodia Daily, 28 May 2014.

Rodriguez-Garavito, C. 2005. 'Global governance and labour rights: codes of conduct and anti-sweatshop struggles in global apparel factories in Mexico and Guatemala'. Politics and Society, 33:2, 203-233.

Seidman, G. 2007. Beyond the Boycott: Labour Rights, Human Rights, and Transnational Activism. New York: Russell Sage Foundation.

Soule, S. A. 2009. Contention and Corporate Social Responsibility. New York: CUP.

Sourcing Journal. 2014. 'Inditex, H\&M agree to pay up to support wage increase in Cambodia'. Sourcing Journal Online, 23 September 2014. Available at: sourcingjournalonline.com/inditex-hm-agree-pay-support-wage-increase-cambodia/ Accessed on 1 February 2017.

Tarrow, S. 1998. Power in Movement. New York: Cambridge University Press.

Teehan, S. 2014. 'Brands call for trade union law'. The Phnom Penh Post, $20^{\text {th }}$ January 2014.

Teehan, S., Kom, K. and Vidz, T. 2014. 'A brand new strategy'. The Phnom Penh Post, 18 September 2014 .

Tilly, C. 1978. From Mobilization to Revolution. Reading, MA: Addison-Wesley.

Tilly, C. 1999. 'From interactions to outcomes in social movements'. In How Social Movements Matter, ed. M. Guigni, D.McAdam, C. Tilly, pp. 253-270. Minneapolis: Univ. Minn. Press. 
Walker, E. T. and Rea, C. M. 2014. 'The political mobilization of firms and industries', Annual Review of Sociology, 40: 1, 281-304.

Ward, K. and Mouyly, V. 2016. 'Employment relations and political transition in Cambodia', Journal of Industrial Relations, 58: 2, 258-272.

Yaziji, M. and Doh, J. 2009. NGOs and Corporations: Conflict and Collaboration. New York: Cambridge University Press.

Zsombor, P. 2015. 'Garment brands failing on pledge to raise prices'. The Cambodia Daily, 10 December 2015. 